Article

\title{
Grey Water Reuse for Agricultural Purposes in the Jordan Valley: Household Survey Results in Deir Alla
}

\section{Othman A. Al-Mashaqbeh ${ }^{1, *}$, Ayoup M. Ghrair ${ }^{1}$ and Sharon B. Megdal ${ }^{2}$}

1 Royal Scientific Society, Knowledge, Amman-al Jubaiha 11941, Jordan;

E-Mail: ayoup.ghrair@rss.jo

2 Water Resources Research Center, University of Arizona, Tucson, AZ 85721, USA;

E-Mail:smegdal@cals.arizona.edu

* Author to whom correspondence should be addressed; E-Mail: othman.mashaqbeh@rss.jo; Tel.: +962-6-5344701; Fax: +962-6-5344806.

Received: 19 June 2012; in revised form: 19 July 2012 / Accepted: 20 July 2012 /

Published: 6 August 2012

\begin{abstract}
Installation of decentralized grey water treatment systems in small rural communities contributes to a more sustainable water supply. In order to gauge community attitudes about collection and use of grey water, a door-to-door survey in the farming community of Deir Alla, Jordan was conducted by Royal Scientific Society interviewers. Outcomes of a detailed survey, designed specifically for this project, offer insights on people's views on general water and wastewater issues, as well as their motivation, practices and concerns related to using grey water treatment for a portion of their household wastewater and reuse of the treated grey water for irrigation. A total of 47 respondents from different socio-economic background, aged over 18 years, from this community in the Jordan valley took part in the survey. The level of formal education of the respondents was low, and most of households' incomes were below the poverty line in Jordan. Most of the respondents reported that the quality of water supplied by public network is acceptable, but the quantity is insufficient to meet their demand, with supplies being delivered to the household once a week. Respondents relied on the public water network as a first-most important resource $(85.1 \%)$, and $57.4 \%$ of the respondent relied on private water tankers as a second-most important resource in addition to the public network. However, $6 \%$ of the respondents relied only on private water tankers with no access to the public network. Storage tanks are common practice in all the houses in order to store enough water for at least one week. The survey responses provide evidence that rural communities are willing
\end{abstract}


to accept reuse of treated grey water for irrigation. Furthermore, some of people in the studied area are willing to learn more about grey water treatment and reuse in order to operate grey water systems for irrigation purposes. Water scarcity in this rural area of Jordan is the main determinant of willingness to reuse the grey water, rather than socio-economic variables.

Keywords: grey water; reuse; wastewater; Jordan; water supply; rural community; water sustainability; cesspools; irrigation

\section{Introduction}

Jordan is located in an arid to semi-arid region and is one of the most water-scarce countries in the world, ranking fourth worldwide according to Food and Agriculture Organization of the United Nations (FAO) [1]. National consumption of water has increased by almost $50 \%$ over the twenty-year period 1985-2005, and a rising population has nearly tripled municipal water consumption. In 2005, agricultural use represented $64 \%$ of annual Jordanian water use; it is estimated to increase up to $70 \%$ in 2020 [2]. Domestic water demand will continue to increase with the growth of the Jordanian population and economy [3-5]. The scarcity of water resources and its low quality, particularly in terms of salinity, restrict the sustainable development of the agricultural economy in rural Jordan. However, the increased generation of wastewater associated with population growth offers opportunities to treat and utilize this renewable source of water in a decentralized or local setting. This paper reports on a survey study designed to assess attitudes toward converting household wastewater to usable grey water. The treated grey water would provide agriculture with a cost-effective, locally generated source of water, thereby matching the quality of water to the use and releasing pressure on the national water grid.

Grey water is a wastewater derived from kitchens, bathrooms (i.e., discharges from shower, hand basin, bath), and laundry water. Grey water does not include the wastewater produced from toilet use, which is considered black water. The generated quantity of grey water can greatly vary between different households within one community and depends on different factors, such as availability of water and lifestyle of household. In general, the volume of grey water accounts between $50 \%$ and $80 \%$ of the domestic household water uses [6-8]. According to [9], the domestic generated grey water volume in Jordan is approximately estimated about 50 liters per capita per day (L/c/d).

The quality of grey water is highly variable due to the variability in household water use. Grey water contains the same contaminants (organic compounds, nutrients and pathogens) as raw sewage water. However, grey water contains low concentrations of contaminants compared to those in raw sewage water and black water [10,11]. Some question its use given the potential risks, as there is some concern that the high levels of organic load produced in kitchens might pose an unacceptable risk of pathogenic contamination in grey water [12]. Others see treatment and reuse of grey water systems as an opportunity to conserve potable quality water, generate locally sustainable water sources, and match the water supply quality with that required for the intended use [13-15]. Grey water use, therefore, is under study and of interest to water management agencies and scientists. 
Different types grey water treatment systems have been developed and installed, such as sand filtration, activated sludge systems, aerobic and anaerobic bio-filters, bio-rotors and submerged aerated filters, bio-rolls $[15,16]$. However, implementation of grey water systems with simple installation, operation, maintenance, cost and energy requirements will assist in rural community adoption of these systems for reuse of a portion of their effluents for irrigation.

A few shining examples of conservation and waste recycling exist. In Jordan and Tunisia, controlled wastewater use is practiced with significant positive impact on those countries' water budgets. Outside the Middle East and North Africa region, other countries have employed a proactive policy of reclaiming wastewater for productive use including the USA (California and Arizona) and Australia [6]. Generally, rural areas at Jordan lack sanitation networks and treatment systems. Therefore, discharge of wastewater to a cesspool is the main common sanitation practice among households. This is considered one of main threats that might contaminate the groundwater resources. Diverting the grey water out of cesspool in rural areas can minimize the negative effects of cesspool (i.e., reducing the seepage from cesspool to groundwater), replace fresh water use, reduce the costs of cesspool maintenance, and provide more sustainable water supply in regions where the water resources are limited and irrigation water is needed.

Recycling treated wastewater for food production is less common than reusing treated wastewater for municipal uses, such as public parks, schools and golf courses [17]. Yet, use of recycled water by agriculture is common in some countries of the world, particularly where water is simply unavailable or the economic incentive to reuse is substantial. It is estimated that 20 million farmers worldwide use untreated or partially treated wastewater [18].

This paper reports on the results of an investigation and assessment of local community views through a household survey on general water and wastewater issues, including their motivation, practices and concerns related to using grey water treatment and reuse for irrigation. The survey, administered in Arabic via in-person interviews, collected data from rural households in Jordan covering socioeconomic data, water sources and uses issues, wastewater and sanitation practices, and grey water perspectives. Conducting the survey is part of the project effort to assess attitudes toward grey water use prior to introducing grey water use in the Jordan Valley. In addition to providing useful information for project demonstration, it enabled the project team to meet the goal of actively involving many from the local community in the project.

\section{Methodology}

\subsection{Household Survey}

As noted, this household survey study is part of a large research project to install and operate a demonstration grey water collection, filtration, and distribution systems at the study area. Therefore, in order to familiarize people with the activities of the project, many interviews and meetings were conducted with the concerned people in the study area such as the officials at the Deir-Alla municipality, and some local people from nearby study area. In addition, site visits to select the proper site to install the proposed multi-layer filter grey water system were made. The local community involvement in this 
project included questionnaires, information gathering visits, installing and operating a demonstration grey water collection, filtration, and distribution system.

It has been noticed from the literature that many studies have conducted household surveys on different issues related to grey water [19-23]. The survey questionnaire structure and questions used for the current study were developed by project research team based on reviewing similar questionnaires on grey water in the literature and insights gained during the preliminary visits to the study area.

The specially designed survey was comprised of 35 questions, which were divided into four groups. The first group (Q 1-6) was about socio-economic characteristics of the respondents, such as gender, age group, education level, income level and the number of people living in the household. The second group (Q 7-23) focused on water sources and uses issues (quality and quantity), such as average amount of water consumption at the house, the participant's views on public water quality and quantity, main sources of water used for different uses in the house, and household water saving practices. The third group $(\mathrm{Q}$ 14-18) requested wastewater and sanitation data. In this part, the respondents were asked about the discharging of their wastewater, specifically asking about water from the kitchen, laundry, showers and hand washing basins, as well as type of cesspools. The fourth group of the survey (Q 30-34) was focused on grey water. The respondents were asked about their knowledge of grey water concept, willingness to reuse grey water, their acceptance of reusing treated grey water and follow up and operate the grey water treatment unit. The survey also included an open-ended question (Q 35) that asked all respondents for their views, suggestions and recommendations on treating household grey water and different purposes for its reuse (The household questionnaire is shown in Appendix A).

The sampling process consists of two stages; first, a stratified random sample of five census areas was selected. Second, interviewers carried out a door-to-door meeting within each census area. Forty-seven questionnaires were filled during face to face meetings with the families of the studied area. General observations were also reported by interviewers of any environmental considerations inside the houses related to the grey water.

\subsection{Survey Data Analysis}

The survey data collected during the study were gathered from two types of questions; the first type was closed-ended questions, and their responses were analyzed using SPSS version-10 to obtain key trends and examine the interrelationship of responses to different survey questions in average and median percentage and graphical forms.

The second type was open-ended questions, which were included in the survey so the respondents could express their opinions, suggestions and recommendations. These responses were manually analyzed to develop suggestions and recommendations to minimize the challenges which are facing the community regarding the grey water reuse. Forty-seven homes in the Deir Alla region were visited. Forty-seven questionnaires were completed by homeowners for a $100 \%$ response rate. 


\section{Results and Discussion}

\subsection{Description of Study Area}

Deir Alla (Um-Ayyaash area) is located in the Middle Ghor (the area situated between the villages of Kreymeh and Karameh) along the main Jordan Valley road, a short distance southwest from Ajloun and $50 \mathrm{~km}$ north of the Dead Sea. It lies from the village of Kreymeh in the North to the village of Al Muaddi in the South (Figure 1). The city is considered a tourist attraction and has an impressive temple that was built on the hill of Deir Alla around 1500 BC.

Figure 1. Location map of the studied area, DeirAlla, Jordan (Um-Ayyaash area).

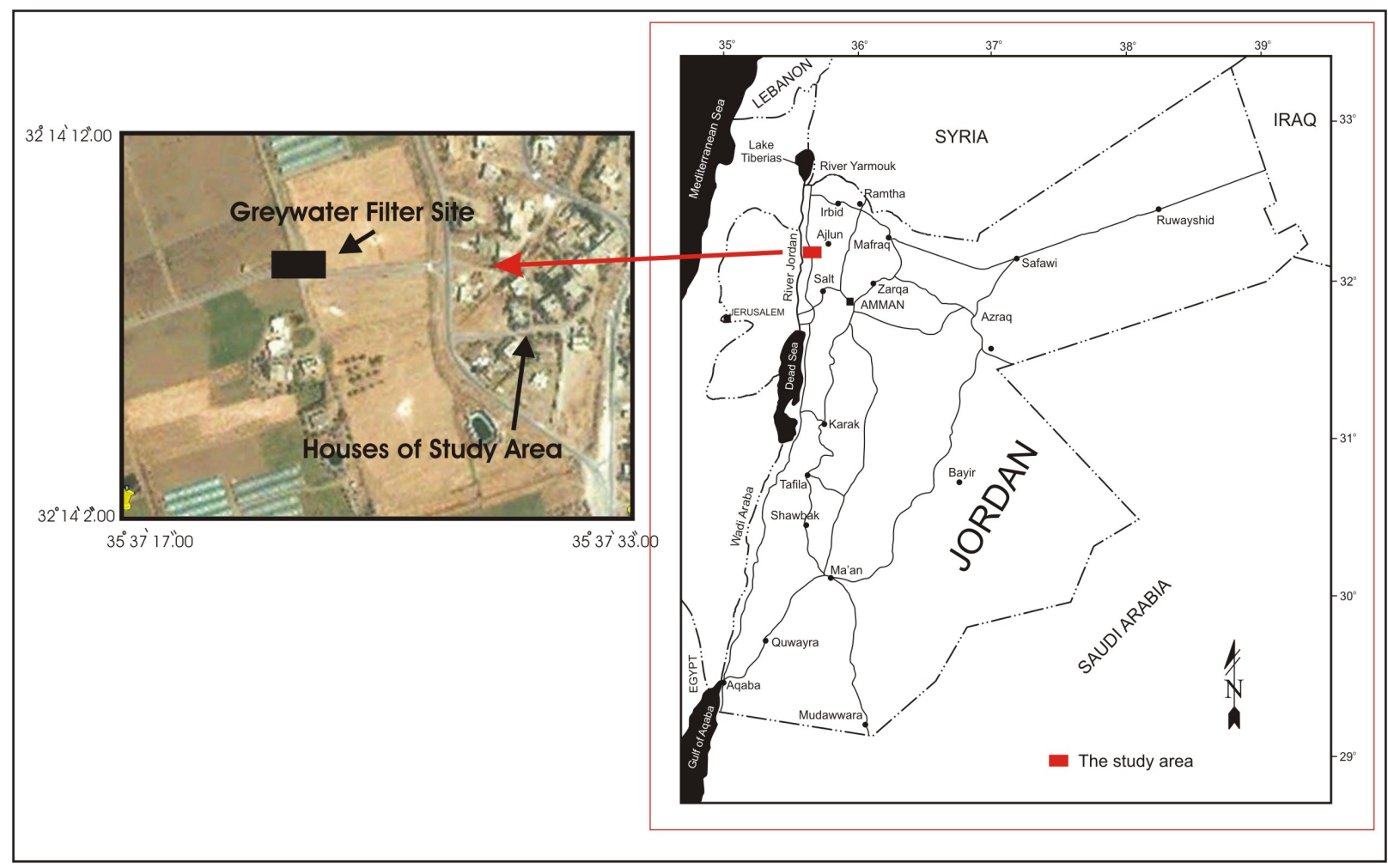

Agriculture is one of the primary economic activities in the studied area, as it is in Jordan Valley in general. Intensive irrigated agriculture has been in place in this region since the 1960s. The main planted crops are vegetables and fruit trees, with $98 \%$ of them are irrigated [24]. The vegetable cultivation under greenhouses cover $50 \%-70 \%$ of the total irrigated area [25]. It has been observed during survey meetings that large areas planted with different crops are surrounding the houses. The main source of irrigation water in Jordan Valley is King Abdullah Canal (KAC). This source of these crops is mainly a blended water (treated wastewater mixed with fresh water) which is provided from the King Talal Dam (KTD) and from Yarmouk River via the King Abdullah Canal (KAC). The irrigation water has been priced by the Ministry of Water and Irrigation/Jordan Valley Authority since 1995. Different prices have been applied depending on the quality and the consumption quantity of irrigation water [26].

According to the Department of Statistics data [27], the estimated population of the Deir Alla region for 2011 was 56,180. Most of families in study area rely on agriculture for their livelihood. Annual 
precipitation and temperatures are shown in Figure 2. It is very clear in the figure that the low values of precipitation and the high temperature at winter season of the Deir Alla region provide suitable environmental conditions (simulating a kind of large green house) to increase the production of winter-season crops.

Figure 2. Average annual precipitation and temperature for Deir Alla region [28].
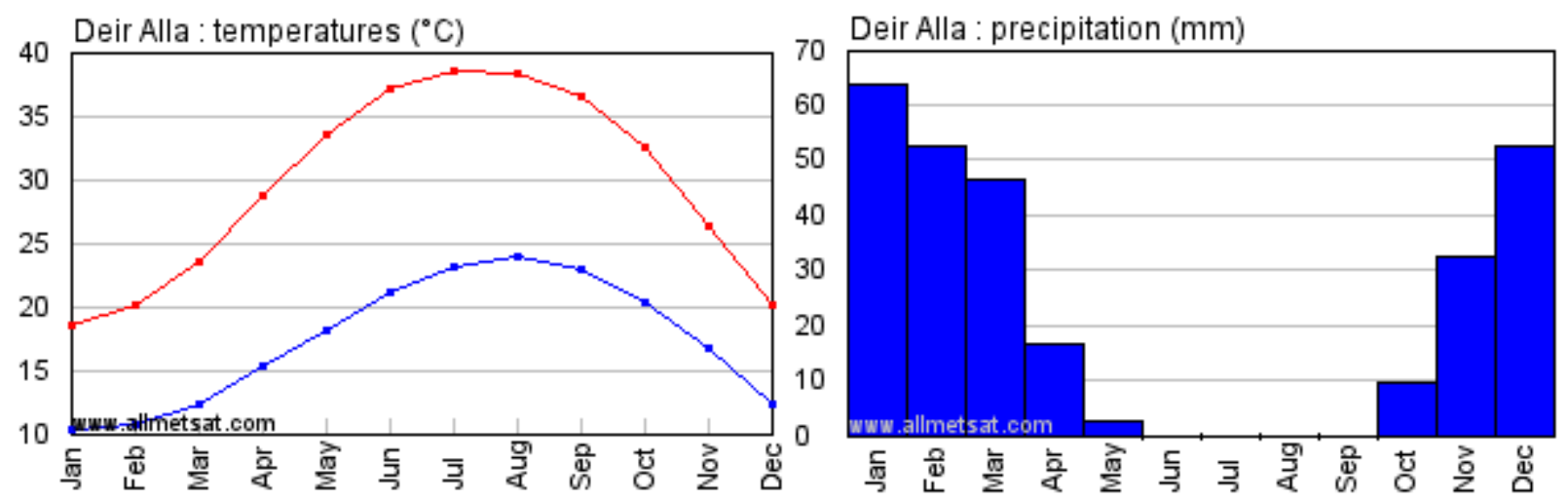

\subsection{Socio-Economic Characteristics}

The effective participation of public and building trust with local communities by involving them at the planning process and in collecting data, selecting alternative sites and technologies, and having an input in the management of a project, are very important to ensuring the cooperative management of community resources and sustainability of demonstration grey water systems [29]. Gathering information directly from local people is likewise very important to identifying an overall picture, rather than looking for statistical significance, and emphasizing the importance of local knowledge [30]. Therefore, the responses of the survey questions were collected using face-to-face meetings at the respondents' houses.

The socio-economic characteristics of the visited houses in the study area were similar. The characteristics investigated include gender, age, monthly income, level of education and family size. The responses show that the gender of the respondents was $55.3 \%$ male and $44.6 \%$ female, with $31.9 \%$ of their ages ranging between 35 years and 49 years. Most of the respondents (57\%) had low educational level (illiterate and elementary) and $24.4 \%$ of them had a category of monthly income (150-250) Jordanian Dinar (JD). The average number of family members was (8.8) members, which is higher than (5.4) the average household family size in Jordan [31]. This is due to the household composition of the study area has two type of family structure, nuclear and extended family. Nuclear family is usually defined as a family unit of both parents and their children, which account for about $78.3 \%$ of the households. However, an extended family includes family members other than parents and children such as a grandparents, aunts and uncles, or cousins. Extended families account for about $21.7 \%$ of the households.

The socioeconomic data show a low level of formal education. Only few people in the communities held university degrees (10.6\%). The major occupations of the respondents were housekeeping and farming. Most household incomes (64\%) were below the poverty line in Jordan. According to the Poverty Report published by the Department of Statistics, based on the Household Income and 
Expenditures Survey of 2008 [32], the poverty line was JD57 per person per month and JD3876 per household (5.7 people) or JD323 per month.

\subsection{Water resource Scarcity and Uses}

A majority of survey respondents, regardless of their age and gender, agreed that water availability for different uses is a key concern: $42.2 \%$ of the survey respondents mentioned that the water supplied by public network is insufficient and they are relying on other resources such as buying water tankers to cover their different water uses. This result is in harmony with [3]. This report stated that current renewable supply only meets about half of total water demand in the Kingdom. Currently, the shortage of supply is met by over-pumping of groundwater. However, this approach cannot be long-maintained. Exceeding the safe yield level by groundwater extraction eventually leads to the reduction of natural groundwater outflows. Consequently, significant reduction in aquifer water level is a risk of permanent damage to the aquifer [3].

The water supply by public network has been intermittent in Jordan since 1987 [33]. It has been based on a system of rationing, with households receiving water once a week for various durations. Indeed, a similar trend has been noticed for water supply regime of studied area from survey data. Approximately $80 \%$ of survey respondents mentioned that the water supply by public network is reaching the household once a week and $10.9 \%$ reported twice a week, while no one reported that the water reached their homes on a daily basis. Therefore, all households surveyed had storage tanks large enough to store water for at least one week. A study reported that the intermittent supply in Jordan leads many households to rely on bottled or private water tankers, which is about 8 to 10 times more expensive than public piped water [34].

The survey respondents have ranked their household water resources in terms of importance as follows: the public network was ranked as a first-most important resource by $93.5 \%$ of the respondents; and $67.4 \%$ of the respondent relied on private water tankers as a second-most important resource in addition to the public network, particularly in the summer season as their water consumption increased, however, $6 \%$ of the respondents relied only on private water tankers without no access to the public network. An interesting finding is that, despite the fact that the quality of private water tankers was considered acceptable to only $64.3 \%$ of the sample and the average cost per 1 cubic meter $\left(\mathrm{m}^{3}\right)$ is $4 \mathrm{JD}$, which is considered very expensive compared with water public network, the private water tankers are still considered a valuable source. It is believed that this is a strong indicator for the water scarcity in the studied area. The respondents in this survey were asked about their concerns regarding the quality of supplied water via public network to their homes. The survey data show that $89.1 \%$ of respondents reported that the water quality is acceptable, while $10.9 \%$ reported that the water quality is unacceptable.

The primary water uses in the studied area are domestic, livestock watering and garden irrigation use. The data from this survey indicate that the first-most important household use of water was for domestic purposes (100\%). However, 37\% of the survey respondents have reported that they are using the public network water to irrigate garden crops as second-most important use. This is clear evidence that the amount of supplied irrigation water through the King Abdullah Canal is not enough to cover the demand for irrigation water. The frequency of house garden irrigation depends on the arrival of water from the public network, which is normally available once a week. It is useful to mention here 
that fresh water supplied by the public network is more expensive than irrigation water that is provided by KAC.

In water scarce regions in particular, it is unwise to irrigate with water that meets potable standards when plants thrive on used water containing small bits of compost. Unlike a lot of ecological stopgap measures, grey water reuse is a part of the fundamental solution to many ecological problems currently and into the future. The benefits of grey water recycling include: lower fresh water use (saving money and increasing the effective water supply in regions where irrigation is needed); less strain on failing septic tank or treatment plant; better treatment (top soil is many times more effective than subsoil or treatment plant); less energy and chemical use; groundwater recharge; plant growth; reclamation of otherwise wasted nutrients; and increased awareness of and sensitivity to natural cycles. Grey water use yields the satisfaction of taking responsibility for the wise husbandry of an important resource.

Raising livestock exists in studied area but at a small scale. Only $12.5 \%$ of the survey respondents keep livestock such as local fowls, sheep, goats and cattle, while the rest of them do not raise livestock. Moreover, all of the livestock owners are not facing difficulties in providing sufficient amount of drinking water for their livestock, and all of them indicated that they are using the public network as a main source for watering livestock. The frequency of house garden irrigation and livestock watering depends on the arrival of water from the public network, which is normally available once a week.

Another important finding of this survey is the lack of water harvesting practices (rainwater harvesting) by people living in the studied area. Survey data indicated that all of survey respondents do not collect rainwater. This clearly indicates that there is more people can do at the household level to overcome the water scarcity in the study area. It is believed that the government can play a major role in this situation to increase the public awareness in these communities about water harvesting techniques and also what they should do in the future to cope with the on-going water scarcity in the region.

\subsection{Waste Water Sanitation Practices}

The Deir-Alla region does not have a sewer network system to collect the generated wastewater by households. According to the Water Ministry data on 2007, around 61\% of the total households in Jordan are connected to the sewer network system and the other $39 \%$ of Jordanian households are not connected [33]. This means that most of the non-connected households (40\%) discharge their waste water into cesspools, which is considered as one of major contamination threats to groundwater [35]. The survey shows that each house has at least one cesspool. The average cost of cesspool pumping is $20 \mathrm{JD} /$ Month. The survey shows that there is no separation of wastewater inside the house based on source, such as kitchen, toilet, showers and laundry. Moreover, the vast majority of the survey respondents (95.6\%) discharge all their wastewater (grey water and black toilet water) generated from kitchen, washing, hand washing, shower and toilet to the cesspool. Only, 4.4\% reported that they directly irrigate with grey water their garden and trees. The survey shows that $63 \%$ of the survey respondents have one shower basin in their houses. This indicates that the amount of grey water produced by showers will be promising in spite of low economic situation of the community studied.

Also, it was observed through the discussions with the some respondents that some people are conscious of the environmental issues for cesspool and many of them are willing to undertake any affordable action to minimize the negative effects of the existing wastewater disposal practices. 


\subsection{Public Acceptance and Motivation for Reusing Grey Water}

Agriculture constitutes the main source of employment of the majority of the world's poor, and Jordan is no exception [36]. In total, the share of agriculture in total employment in developing countries constitutes $53 \%$ of the total workforce in 2004 [36]. Increasing and maintaining productivity in agriculture is an important target for science and technology efforts. Finding new and sustainable water resources for irrigation is important to achieving this ultimate target. The concept of reusing grey water has been introduced to the studied area through survey meetings with local community members. Some, albeit a low percentage $(<5 \%)$, have mentioned that they are currently reusing grey water coming out of the sinks and showers for some domestic uses, such as washing their backyards and wiping the surrounding surfaces of owned landscape.

It is been reported in the literature that the relationship between socioeconomic variables (such as income, gender, age or education) and the likelihood of households using alternative water supplies is unclear [37]. The responses of survey respondents provide evidence that local community is willing to accept reuse of treated grey water for irrigation of agriculture crops and gardens. The survey data revealed that $70.5 \%$ of the respondents fully agreed with the re-use of grey water, while $13.6 \%$ disagreed with, and the rest of respondents $(15.9 \%)$ unable to decide whether to accept or reject the reuse of grey water for irrigation. A similar finding has been reported in the literature by [37], who investigated the relationship between socioeconomic variables (age, gender, income and education) and use of grey water in the garden in Australia. They reported that $65.8 \%$ reused grey water for gardens/lawns. It is interested to note that the socio-economic characteristics of the respondents of that study [37] (Income $\sim \$ 78,463$, Education $\sim 49 \%$ post-grad degree) are higher than the average Australian Capital Territory citizen census for 2006 and much higher than those reported in this study. However, in spite of the big difference between the socio-economic characteristics of the two studies, the percent of respondents indicating willingness to reuse grey water in this study is slightly higher than those in [37]. A possible reason for this is that the people in this study are very concerned about securing their irrigation water given the severe shortage of water resources. This suggests that water scarcity in this rural area of Jordan is the main determinant of willingness to reuse the grey water compared with socio-economic variables such as income and education level.

Furthermore, $73.2 \%$ of people in studied area expressed their willingness to learn more about grey water treatment and reuse in order to continue operate the grey water systems that will be installed in their houses.

One of the interesting findings of this study is that about $93 \%$ of the respondents were not aware of the grey water concept and its potential importance to their community, including reuse of grey water for irrigation at their home gardens. This suggests that there is a crucial need to implement appropriate educational program for the community on the best practices on reuse of grey water in order to encourage and spread the implementation of reuse grey water concept around homes. The development of community knowledge about grey water related subjects in Jordan can be increased through awareness campaigns, site visits, workshops, regular meetings, and group discussions [38]. 


\section{Conclusions}

The survey results showed that the socio-economic characteristics of the study area are generally very difficult. The families are poor and with low education levels. The main source of income for the local people is derived from agricultural activities. However, in spite of all these considerations, people are still willing to accept the reuse of grey water and to adapt its treatment in order to secure their water needs for irrigation due to severe shortage of water resources in the study area.

The government and people of Jordan can jointly implement appropriate demand management solutions to reduce the threat of running out of water. Practical actions, such as increasing awareness and education, reforming of policy and law, developing and commercializing new technology, as well as training of local community on best practices of grey water treatment and reuse, should be pursued to secure water supplies and achieve sustainability of water resources in rural areas. The authors recognize that other areas of the world have similar motivations to achieve more sustainable water use practices and hope that this survey can be adapted for administration in other locations.

\section{Acknowledgments}

The authors would like to express thanks to Royal Scientific Society, Deir Alla municipality and Al-Basmalla assembly for providing transportation vehicles, engineering staff as well as data collection. Many thanks go to the research team Hamad bany Hamad, Rana Ardah, Tharwa Quteish, Soheil Nosir, Ammany Mahasnah, Ayman Qamoh, Jameel Hadad, Jihan Haddad, Atheel Lozzi, Nojood Al-Bataineh and Ahmed Gharaibeh from Natural Resources Authority for their efforts throughout the project and many fruitful discussions. Partial funding for this research was provided by USAID Economic Development Program (SABEQ program-Jordan). In addition, the project benefited from discussions at two workshops sponsored by RSS EWE-CT Center and USAID. Sharon B. Megdal was supported in part by the University of Arizona Water Sustainability Program, which is funded by the Technology Research Initiative Fund. Finally, the authors extend special thanks to Charles G. Graf from Water Quality Division, Arizona Department of Environment Quality, USA for reviewing the household survey.

\section{References}

1. FAO. Coping with Water Scarcity. Challenge of the Twenty-First Century UN-Water; Food and Agriculture Organization: Rome, Italy, 2007.

2. National Master Water Plan (NWMP). National Master Water Plan Water Resources in Jordan; Water and Irrigation Ministry: Amman, Jordan, 2004; Volume 3.

3. USAID Economic Development Program. Responding to the Water Crisis in Jordan; USAID: Amman, Jordan, 2005.

4. National Research Council. Water for the Future: The West Bank and Gaza Strip, Israel, and Jordan; The National Academies Press: Washington, DC, USA, 1999.

5. Salamah, E. Water Quality Degradation in Jordan (Impacts on Environment, Economy and Future Generation Resources); FES and RSCN: Amman, Jordan, 1995; pp. 1-179. 
6. Redwood, M. Greywater irrigation: Challenges and opportunities. In CAB Reviews: Perspectives in Agriculture, Veterinary Science, Nutrition and Natural Resources; CAB International: London, UK, 2008; No. 063.

7. Eriksson, E.; Auffarth, K.; Henze, M.; Ledin, A. Characteristics of grey wastewater. Urban Water 2002, 4, 85-104.

8. Burnat, J.; Eshtayah, I. On-site greywater treatment in Qebia Village, Palestine. In Greywater Use in the Middle East; Mcllwaine, S., Redwood, M., Eds.; IDRC: Ottawa, Canada, 2010. Available Online: http://web.idrc.ca/en/ev-152492-201-1-DO_TOPIC.html (accessed on 31 March 2012).

9. Faruqui, N.; Al-Jayyousi, O. Greywater reuse in urban agriculture for poverty alleviation-A case study in Jordan. Water Intern. 2002, 27, 387-394.

10. Otterpohl, R. Options for alternative types of sewerage and treatment systems directed to improvement of the overall performance. Water Sci. Tech. 2002, 45, 149-158.

11. World Health Organisation (WHO). Guidelines for the Safe Use of Waste-water, Excreta and Greywater; WHO: Geneva, Switzerland, 2006; Volumes 1-4.

12. Casanova, L.M.; Little, V.; Frye, R.J.; Gerba, C.P. A survey of the microbiological quality of household graywater. J. Am. Water Resour. Assoc. 2001, 37, 1313-1319.

13. Noah, M. Graywater use is still a gray area. J. Environ. Health 2002, 64, 22-25.

14. Morel, A.; Diener, S. Greywater Management in Low and Middle-Income Countries, Review of Different Treatment Systems for Households or Neighbourhoods; Swiss Federal Institute of Aquatic Science and Technology (Eawag): Dubendorf, Switzerland, 2006.

15. Allen, L.; Christian-Smith, J.; Palaniappan, M. Overview of Greywater Reuse: The Potential of Greywater Systems to Aid Sustainable Water Management; Pacific Institute Report, Oakland, CA, USA, 2010. Available online: http://www.pacinst.org/reports/greywater_overview/ greywater_overview.pdf (accessed on 31 July 2012).

16. Friedler, E.; Kovalio, R.; Galil, N.I. On-site greywater treatment and reuse in multistory buildings. Water Sci. Tech. 2005, 51, 187-194.

17. Megdal, S.B. Municipal Water Reuse in Tucson, Arizona. In Wastewater Reuse-Risk Assessment, Decision-Making and Environmental Security; Zaidi, M.K., Ed.; Springer, AK/Nato Publishing Unit: Dordrecht, The Netherlands, 2007; pp. 81-90.

18. WHO. Using Human Waste Safely for Livelihoods, Food Production and Health: Information Kit on the 3rd Edition of the Guidelines for the Safe Use of Wastewater, Excreta and Greywater in Agriculture and Aquaculture; WHO, FAO: New York, NY, USA, 2008.

19. Carden, K.; Armitage, N.; Winter, K.; Sichone, O.; Rivett, U. Understanding the Use and Disposal of Greywater in the Non-Sewered Areas in South Africa; Report No. 1524/1/07; Water Research Commission: Pretoria, South Africa, 2007.

20. Pinto, U.; Maheshwari, B. Reuse of greywater for irrigation around homes in Australia: Understanding community views, issues and practices. Urban Water J. 2010, 7 (2), 141-153.

21. Pinto, U.; Maheshwari, B. Issues and Challenges of Greywater Reuse for Irrigation in Australia-A Case Study of Western Sydney Region; University of Western Sydney: Sydney, Australia, 2007.

22. Christova-Boal, D. Installation and Evaluation of Domestic Greywater Reuse Systems. M.Sc. Thesis, Victoria University of Technology, Melbourne, Australia, 1995. 
23. Raude, J.M.; Mutua, B.M.; Chemelil, M.C.; Sleytr, K. Characterization of greywater from urban and peri-urban areas of Nakuru municipality, Kenya. In Proceedings of the 34th WEDC International Conference, United Nations Conference Centre, Addis Ababa, Ethiopia, 18-22 May 2009; pp. 609-614.

24. Ministry of Agriculture (MoA). Annual Report. Information and Technology; Ministry of Agriculture: Amman, Jordan, 2006; pp. 1-200.

25. Venot, J-P.; Molle, F.; Hassan, Y. Irrigated Agriculture, Water Pricing and Water Savings in the Lower Jordan River Basin (in Jordan); Research Report; International Water Management Institute: Colombo, Sri Lanka, 2007.

26. Molle, F.; Venot, J.-P.; Hassan, Y. Irrigation in the Jordan Valley: Are water pricing policies overly optimistic? Agric. Water Manag. 2008, 95, 427-438.

27. The Hashemite Kingdom of Jordan Department of Statistics (DOS) Hompage. Available Online: http://www.dos.gov.jo/dos_home_e/main/index.htm (accessed on 31 March 2012).

28. El Dorado Weather Homepage. Available Online: http://www.eldoradocountyweather.com/ climate/jordan/Deir\%20Alla.html (accessed on 31 March 2012).

29. Ockelford, J.; Reed, B. Participatory Planning for Integrated Rural Water Supply and Sanitation Programmes: Guidelines and Manual; Water, Engineering and Development Centre, Loughborough University: England, UK, 2002.

30. Pretty, J.; Vodouhê, S.D. Using rapid or participatory rural appraisal. In Improving Agricultural Extension: A Reference Manual; Swanson, B.E., Bentz, R.P., Sofranko, A.J., Eds.; Food and Agriculture Organization of the United Nations: Rome, Italy, 1998.

31. Department of Statistics (DOS). Jordan in Figures 2010; Department of Statistics: Amman, Jordan, May 2011; Issue 13.

32. Department of Statistics (DOS). Poverty Report. Department of Statistics: Amman, Jordan, 2008.

33. Ministry of Water and Irrigation of Jordan (MoWI). Annual Report 2007; MoWI: Amman, Jordan, 2007. Available Online: http://www.mwi.gov.jo/sites/ar-jo/DocLib2/Forms/AllItems.aspx (accessed on 30 April 2012).

34. Darmame, K.; Potter, R.B. Socio-Economic Variations in Water Consumption, Household Management Strategies and Satisfactions in Greater Amman, Jordan: the Results of a Quantitative Household Survey; Geographical Paper No. 186; University of Reading: Whiteknights, UK, 2009.

35. Jenkins J. The Humanure Handbook: A Guide to Composting Human Manure, 3rd edition; Jenkins Publishing: Grove City, OH, USA, 2005; pp. 1-256.

36. Meijerink, G.; Roza, P. The Role of Agriculture in Economic Development; Markets, Chains and Sustainable Development Strategy and Policy Paper 4; Stichting DLO: Wageningen, The Netherlands, 2007. Available Online: http://www.boci.wur.nl/NR/rdonlyres/98CCE2E3-0FA24274-BCA0-20713CA1E125/62608/Fullreport4_Meijerink_Roza.pdf (accessed 30 July 2012).

37. Ryan, A.M.; Spash, C.L.; Measham, T.G. Socio-economic and psychological predictors of domestic greywater and rainwater collection: Evidence from Australia. J. Hydrol. 2009, 379, 164-171.

38. Mcllwaine, S.; Redwood, M. Greywater Use in the Middle East Technical, Social, Economic and Policy Issues; Replika Press: Haryana, India, 2010; pp. 1-162. 


\section{Appendix: Household Questionnaire (Translated to English from Arabic)}

\section{A-Socioeconomic data:}

Q.1 Head of the House name -Telephone No. ( )

Q.2 Gender of the house head:
$\square \quad$ Female
Male

Q.3 Average income (JD ) per Month:

$$
\begin{array}{ll}
\square & <150 \\
\square & 150-250 \\
\square & 250-350 \\
\square & 351-500 \\
\square & 500 \text { or More }
\end{array}
$$

Q.4 Age of the head in years: ( )

Q.5 Education of the head:

$\begin{array}{llll}\square & \text { No formal schooling but read and write } \quad \square \quad \text { Primary } \\ \square & \text { Intermediate } \quad \square \quad \text { Secondary } \quad \square \quad \text { Diploma } \\ \square & \text { Bachelor degree } \quad \square \quad \text { More than Bachelor degree } \\ \square & \text { Limited reading and/or writing }\end{array}$

Q.6 The number of the family members is ( 


\section{B-Water sources and uses (quality and quantity) Data:}

Q.7 How much is the average amount of water consumption from your water bill (m3)? How much do you pay for that (JD)?

Q.8 Do you receive enough water for your uses from the water network system?

Yes $\quad \square \quad$ No

Q.9 On average how frequently do you receive public water? (One choice)
Daily
Two times / week
Once/week
Less than once a week

Q.10 The quality of supplied water to your house is:
Accepted
Not accepted

Q.11 What is the main source of water used for all your uses? (Please write in the box 1 for your main source of water: 2 for your second-most important source; and 3 for the third-most important source of water, and then mark the rest of other used water resources).

$\begin{array}{ll}\square & \text { Piped water } \\ \square & \text { Bottled water } \\ \square & \text { Water from local purification plants } \\ \square & \text { Collected rain water } \\ \square & \text { Tank trucks water } \\ \square & \text { Spring water } \\ \square & \text { Surface water } \\ \square & \text { Groundwater well } \\ \square & \text { Others ( ) }\end{array}$

Q.12 What are the main uses of your water? (Please write in the box 1 for your most important use of water: 2 for your second-most important use; and 3 for the third-most important use of water, and then mark the rest of other used water resources).

Household uses ( such as Drinking, washing, laundry)

Agriculture irrigation ( trees and vegetables)

Animal feeding

All above

Others (

Q.13 How many storage tanks do you have at your house? (

), and how much is the total capacity of these tanks? ( ) $\mathrm{m} 3$

Q.14The water meter at your house is:

Shared with other houses

Not shared (Independent)

Q.15 Do you buy the Tank trucks water?

Yes 
If your answer is yes please answer the following:

a. How many times do you buy Tank trucks water per month?

b. How much is the price of Tank trucks water (for one trip)?

Q.16 What are the uses of the Tank trucks water?

Drinking

Agriculture Irrigation

Animal feeding

All above

Others (

Q.17 How do you describe the quality of Tank trucks water?

Accepted $\square \quad$ Not accepted

Q.18 Do you collect the rain water inside storage tanks:

Yes $\quad \square \quad$ No

If yes please answer the following:

How much is the total capacity of these tanks? ( m3)

How many times these tanks are getting full from rainfall at winter season?

Q.19 What are the main uses of the collected rainwater:

Household uses (such as Drinking, washing, laundry)

Agriculture irrigation (trees and vegetables)

Animal feeding

All above

Others ( )

Q.20 How much time you need to consume the whole collected rain water? ( )

Q.21 Do you use the water for agriculture irrigation?

If yes please answer the following questions:

What are the sources for your irrigation water? (...............)

What type of agriculture irrigation system are you using (for example; flood, drip, sprinkler)?

How many hours do you need for irrigation every week?

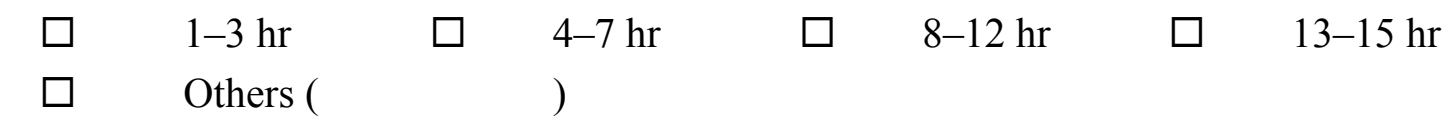

Q.22 Do you have livestock close to you house?
Yes
No

If yes please answer the following:

What is the main water source you are using to feed the animals? (

How much approximately will be the cost of water for animals (

JD/Month)?

(If possible)

Q.23 Do you face any difficulties to provide enough water for animal feeding?

Yes

No 


\section{C-Wastewater and sanitation data:}

Q.24 What type of toilet waste water discharge services you have?

Public network sewer system.

Cesspool.

Out door.

If the answer is Cesspool, please answer the following:

How many cesspools do you have for the house? (

How many times do you pump and empty the wastewater from the cesspool?

Per month? Per year?

How much it cost you for cesspool pumping? (

JD/Month)

Q.25 What type of cesspool design do you have for the wastewater?

Closed tank made of concrete (No seepage of water to the ground soil)

Open tank made of concrete ( Water seeps to the ground soil)

Q.26 The used water in the kitchen and laundry is drained to:

$\square \quad$ Cesspool

$\square \quad$ Storage tank

Agriculture irrigation

Others (

Q.27 Do you have bath tubs or shower in the house:
Yes
No
Others (

If yes please answer the following:

How many bath tubs do you have in the house?

( )

How many showers without bath tubs do you have in the house?

Q.28 The interviewer observes the number of hand washing basins in the house and related to family size: (Number of basins / Number of family members)

Basin for 2 persons or less

Basin for 3-4 persons

Basin for 5 persons and above

No Basins

Q.29 The used water from the shower is drained to:

Cesspool

Storage tank

Agriculture irrigation

Others (

( $\square$ (ize: (Number of basins / Number of family members) 


\section{D-Grey water Data:}

Q.30 Do you know the meaning of Grey Water?
Yes
No

Q.31 Do you separate the grey water from waste water and reuse it?
Yes
No

If Yes answer the following:

What are your main reuses of grey water?

Q.32 If you reuse the grey water for agriculture irrigation, what is the name of plants or crops irrigated by grey water?

Q.33 Do you agree to reuse the laundry, sink washing and shower water after treatment:
$\square \quad$ Not agree
$\square \quad$ I don't know

Q.34 Do you agree to follow up and to operate the grey water treatment unit connected to your house?

Q.35 What are the main comments, suggestions and recommendation regarding the following:

1 -Treating grey water from your house.

2-Reuse grey water in different uses.

(C) 2012 by the authors; licensee MDPI, Basel, Switzerland. This article is an open access article distributed under the terms and conditions of the Creative Commons Attribution license (http://creativecommons.org/licenses/by/3.0/). 